\title{
Forensic Digital Analysis For CCTV Video Recording
}

\author{
Pria Sukamto ${ }^{1}$, Ispandi ${ }^{2}$, Arman Syah Putra ${ }^{3 *}$, Nurul Aisyah ${ }^{4}$, Rohmat Toufiq ${ }^{5}$ \\ ${ }^{1}$ Faculty of Computer, Muhammadiyah Cileungsi College of Technology, Indonesia \\ ${ }^{2}$ Faculty of Information Technology, Nusa Mandiri University, Indonesia \\ ${ }^{3}$ Faculty of Computer, STMIK Insan Pembangunan, Indonesia \\ ${ }^{4}$ Faculty of Economic and Business, Bina Sarana Informatika University, Indonesia \\ ${ }^{5}$ Faculty of Computer, Muhammadiyah Tangerang University, Indonesia \\ ${ }^{*}$ Corresponding author: \\ Email: armansp892@gmail.com
}

\begin{abstract}
.
The background of this research is how to make a video that can be analyzed as forensic data to prove the truth of the video, therefore with forensics it can be used as evidence if the video contains incorrect data or contains data capable of crime so that it can be used as data forensics. The method used in this study is to use the literature review method which uses the basis of many previous studies. From journals and books based on similar research, so that it can help develop existing problems to the latest problems so that they can find novelty in this research. The problem raised in this research is how to make a video from a CCTV that can be proven, by certain methods in order to make the video as forensic data, that can be proven so that it can be developed into data containing crimes that can be used as evidence. The purpose of this study is how to find the right method in order to analyze a CCTV video, so that it can be used as evidence on forensic data with the NIST method, it can be proven that this method is the right method in analyzing a video, so that it can be used as evidence and as data forensics.
\end{abstract}

Keywords : Forensic, Digital Analysis, CCTV, Video Recording.

\section{INTRODUCTION}

Currently the role of CCTV cameras (Closed Circuit Television) is needed as a security system in everyday life, the use of CCTV (Closed Circuit Television) cameras is considered very efficient as a security mechanism that is in demand today because of its ability to anticipate crime in the community. This condition is highly expected by the community to avoid various criminal acts, thus the role and function of CCTV (Closed Circuit Television) cameras today is not only as a tool to monitor the surrounding environment. CCTV (Closed Circuit Television) cameras have the ability to record real-time surroundings, at certain times CCTV (Closed Circuit Television) cameras are used as evidence related to criminal cases. However, CCTV (Closed Circuit Television) camera evidence has special techniques in handling it because the nature of the evidence obtained from camera recordings is volatile or easy to change, very susceptible to modification and removal, easily contaminated by new data, and sensitive to time [1].To maintain the integrity and authenticity of evidence, it is necessary to apply digital forensic science in the investigation of a case. Forensic digital science is used for the practice of dissecting digital devices to find facts needed for legal purposes. In this case, there are two terms that are almost the same, namely electronic evidence and digital evidence [2]. Electronic evidence is in physical form and can be identified visually, such as computers, cellphones, cameras, CDs, hard disks, etc., while digital evidence is in the form of evidence extracted or recovered from electronic evidence, the evidence can be in the form of files, emails , messages, images, videos, logs or text.

According to several cases using CCTV (Closed Circuit Television) cameras, there is still uncertainty regarding the use of CCTV whether CCTV can be used as evidence or as evidence [3].Referring to Law no. 19 of 2016 Article 5 Paragraph 1 (one) and Paragraph 2 (two) concerning Electronic Information and Transactions it is stated that electronic information and/or electronic documents and/or their printouts are legal evidence, which is an extension of evidence. Valid in accordance with the applicable procedural law in Indonesia. In this case, CCTV (Closed Circuit Television) cameras are legal digital evidence and have a 
recording file that provides information in the form of data or commonly known as metadata, where metadata can be recorded on a computer automatically when a file is created, so it can be known when the file was created. Who the author is, what is the file size, and also the extension. Metadata information functions to store, maintain, and manage sources in order to maintain the integrity and integrity of files obtained from CCTV (Closed Circuit Television) cameras [4].In addition to metadata in handling CCTV (Closed Circuit Television) camera digital evidence, there is an essential thing called Chain of Custody. Chain of custody is an effort to maintain and ensure integrity in digital evidence and procedures for documenting evidence chronologically since it was first found at the crime scene (TKP) to explain 5 characteristics ( $4 \mathrm{~W}$ and $1 \mathrm{H}$ ) of Chain of Custody, namely fingerprint of evidences (why), digital signing (who), time stamping (when), geo location (where) and procedures (how). The problem to be developed from this journal is the analysis of the application of Digital Forensic Analysis of CCTV (Closed Circuit Television) Camera Recordings Using the NIST (National Institute of Standards Technology) Method. As for the previous method metadata and hash [5].

\section{THEORETICAL BASIS}

In his book entitled Computer Security Systems, defines Computer Forensics as a science that discusses findings in the form of digital evidence after events related to computer security occur. Digital Forensics can be said to be the application of science to recover digital evidence from a device, be it a computer or smartphone, with certain methods that aim to collect data that can be accepted by the court as one of the evidences. Professional Computer Ethics defines that Cyber Crime is one of the negative impacts of technological developments that cause extensive losses for all modern life today [6].The variable of this development is the NIST method for CCTV (Closed Circuit Television) video recording. Institute of Standards and Technology (NIST). NIST is a method that has four stages in resolving and investigating Cyber Crime cases, the first stage is Collection (Data collection), Examination (Examination of evidence), Analysis, and the last is Reporting (Creating reports based on analysis results) [7].

\section{METHODS}

In the old research, it was a hacking method, the research method would be acquired based on the guidelines and requirements in the Indonesian National Standard (SNI). Several previous studies have used acquisition procedures in accordance with SNI 27037:2014 with the NIST (National Institute of Standards Technology) investigation process method used to analyze the metadata of CCTV (Closed Circuit Television) camera recordings as digital evidence. Figure 1 is the stage of inspection and analysis that will be carried out.The NIST process which consists of several stages, namely the collection (labeling) stage or the collection stage is a series of activities to collect data to support the investigation process in the context of searching for evidence of digital crimes.

At this stage there is a process of collecting data from relevant data sources and maintaining the integrity of evidence from changes, examination (data processing) or this inspection stage is the stage of examining data collected forensically, either automatically or manually, and ensuring that the data obtained in the form of the original file according to what was obtained at the scene, for that digital files need to be identified and validated with hashing techniques, in this examination process testing is carried out using forensic tools, namely Media Info and exif tools used to find camera metadata information CCTV (Closed Circuit Television). Furthermore, the analysis stage (analysis of examination results) or the research stage is carried out after obtaining the desired digital file or data from the previous examination process, then the data is analyzed in detail and comprehensively with methods that are technically and legally justified to be able to prove the data. The results of the analysis of digital data are hereinafter referred to as being used as digital evidence and can be justified scientifically and legally, as valid evidence. 


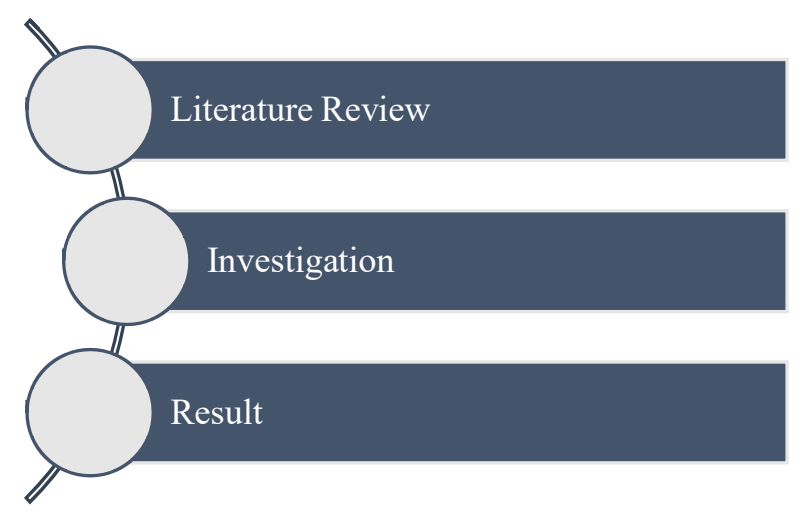

Fig 1. Research Method

\section{RESULT AND DISCUSSION}

The NIST process which consists of several stages, namely the collection (labeling) stage or the collection stage is a series of activities to collect data to support the investigation process in the context of searching for evidence of digital crimes. At this stage there is a process of collecting data from relevant data sources and maintaining the integrity of evidence from changes, examination (data processing) or this inspection stage is the stage of examining data collected forensically, either automatically or manually, and ensuring that the data obtained in the form of the original file in accordance with what was obtained at the scene, for that digital files need to be identified and validated with hashing techniques, in this examination process testing is carried out using forensic tools, namely MediaInfo and Exif tools used to find metadata information on CCTV (Closed Circuit Television) cameras.Furthermore, the analysis stage (analysis of examination results) or the research stage is carried out after obtaining the desired digital file or data from the previous examination process, then the data is analyzed in detail and comprehensively with methods that are technically and legally justified to be able to prove the data. The results of the analysis of digital data are hereinafter referred to as being used as digital evidence and can be justified scientifically and legally as valid evidence.

The NIST process which consists of several stages, namely the collection (labeling) stage or the collection stage is a series of activities to collect data to support the investigation process in the context of searching for evidence of digital crimes. At this stage there is a process of collecting data from relevant data sources and maintaining the integrity of evidence from changes, examination (data processing) or this inspection stage is the stage of examining data collected forensically, either automatically or manually, and ensuring that the data obtained in the form of the original file in accordance with what was obtained at the scene, for that digital files need to be identified and validated with hashing techniques, in this examination process testing is carried out using forensic tools, namely MediaInfo and Exif tools used to find metadata information on CCTV (Closed Circuit Television) cameras . Furthermore, the analysis stage (analysis of examination results) or the research stage is carried out after obtaining the desired digital file or data from the previous examination process, then the data is analyzed in detail and comprehensively with methods that are technically and legally justified to be able to prove the data. The results of the analysis of digital data are hereinafter referred to as being used as digital evidence and can be justified scientifically and legally. as valid evidence.After identifying and labeling the evidence the main thing is to hash it. Where hasing is done to maintain data integrity from data originating from digital evidence. Hashing in this section is an algorithm technique used in the data section to create a unique data set with fixed variable length conditions. Figure 2 is a step to get the Hash value of forensic digital investigations from CCTV (Closed Circuit Television) camera evidence. 


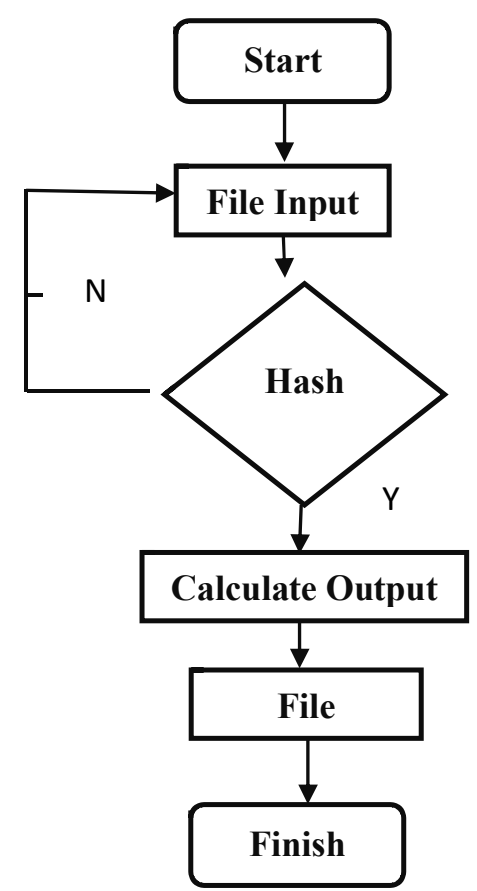

Fig 2. Flowchart Hash

The picture 2 shows the hashing results from digital evidence of CCTV (Closed Circuit Television) camera recordings obtained with files with the extension MD5 (Message Digest algorithm 5) with a length of 32 characters.Next is the examination process which is the stage of testing and processing data collected using forensic tools from MediaInfo and ExifToll. This stage can be seen in Figure 4 with the process of acquiring physical evidence from CCTV (Closed Circuit Television) cameras to obtain video recording files which will then be tested on digital evidence.

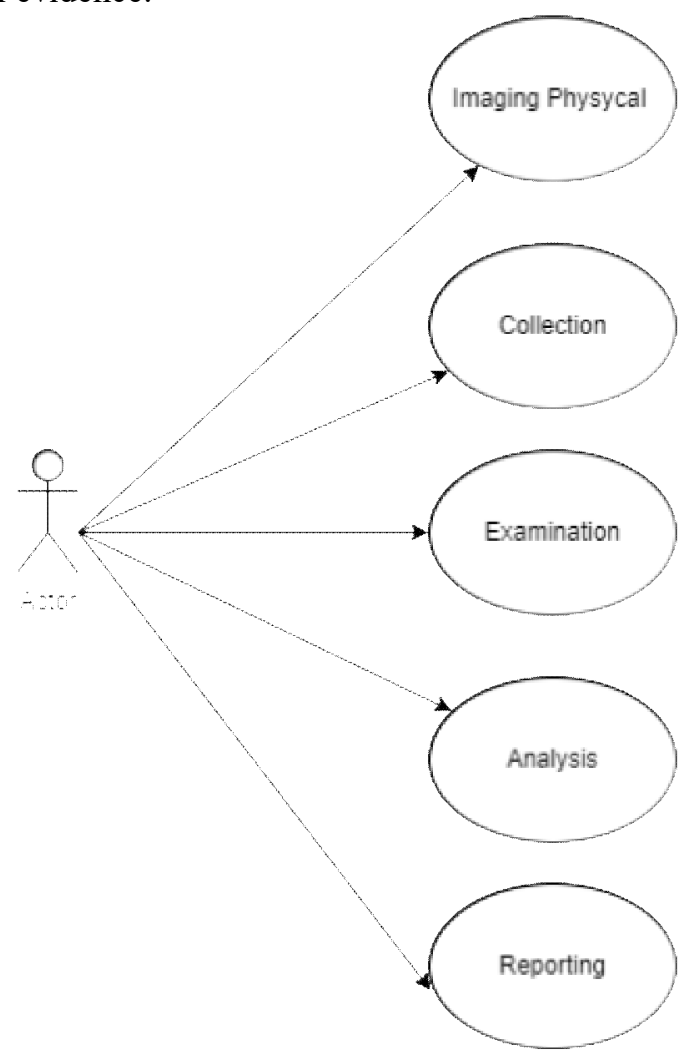

Fig 3. Usecase Diagram

http://ijstm.inarah.co.id 
Enlarge image 3, it will be given an explanation that there is an actor in a use case diagram, namely there is a use case diagram of physical imaging, use case diagram collection, examination use case diagram, use case diagram analysis and the last is use case diagram reporting, the following system is describing how to do this, identification of data in the forensic analysis of a video.

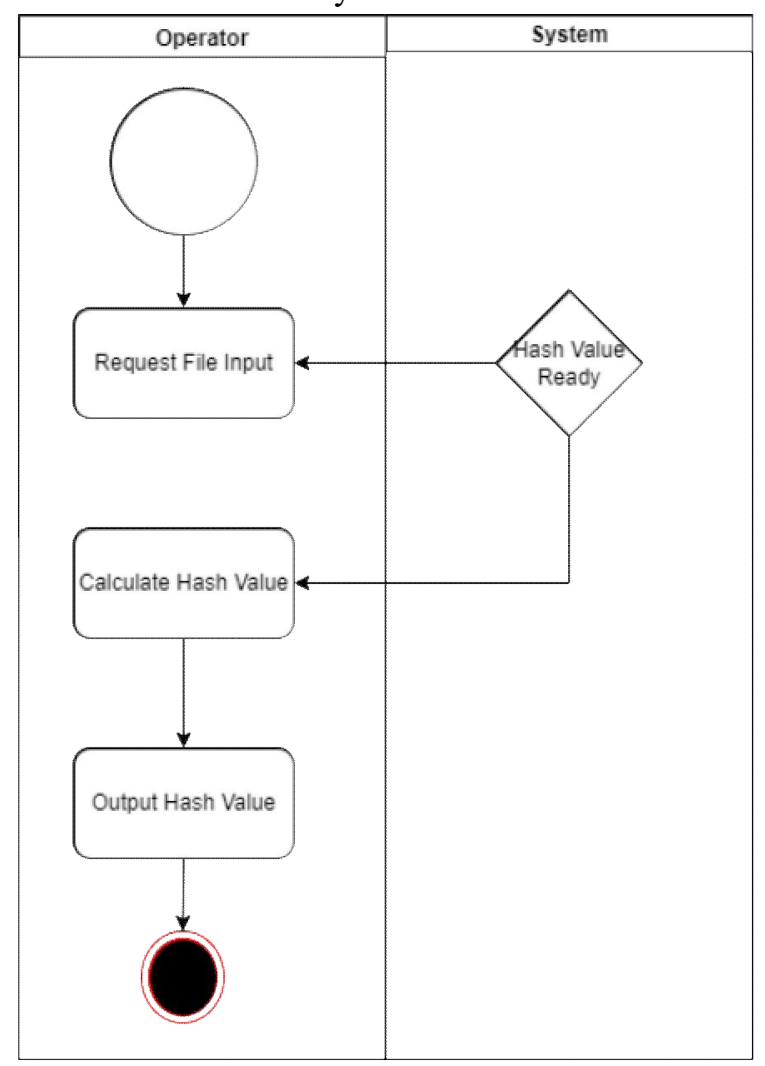

Fig 4. Hash Activity Diagram

Based on Figure 4 above, there is an activity diagram that describes how the process has been able to identify data on a CCTV (Closed Circuit Television) video. The explanation is as follows, the system starts with a start method on the activity diagram, then the system starts asking for files to be inputted after that the system gives a choice between yes. Further or calculating the HASH system after that it will produce Expedia output which contains the results of the video extracted by the HASH.

\section{CONCLUSION}

The development of this research is an attempt to obtain digital evidence of CCTV (Closed Circuit Television) camera recordings that are applied using the NIST (National Institute of Standards Technology) method for forensic digital investigations related to CCTV (Closed Circuit Television) camera recordings in order to obtain file metadata information to be implemented and to process a source of information to be used as a source of information. as evidence that is implemented using the Chain of Custody document so that the integrity of digital evidence is maintained intact from the beginning it is found to the analysis of the information contained in the CCTV (Closed Circuit Television) camera, thus information on evidence obtained from CCTV (Closed Circuit Television) camera recordings can be accepted and used to strengthen evidence in the judge.

\section{REFERENCES}

[1] D. N. M. A. A. P. J. I. D. H. S. Y. C. Arman Syah Putra, "“Examine Relationship of Soft Skills, Hard Skills, Innovation and Performance: the Mediation Effect of Organizational Le," IJSMS, pp. 27-43, 2020.

[2] H. W. Arman Syah Putra, "'Intelligent Traffic Monitoring System (ITMS) for Smart City Based on IoT Monitoring"," 1st 2018 Indonesian Association for Pattern Recognition International Conference, INAPR 2018 - 
Proce vol, 2019.

[3] N. K. Dewi and A. S. Putra, "Perkembangan Gamification dan Dampak Game Online terhadap Jiwa Manusia di Kota Pintar DKI Jakarta," Jurnal Informatika Universitas Pamulang, vol. 5, no. 3, pp. 315-320, 2020.

[4] N. K. Dewi and A. S. Putra, "SISTEM PENUNJANG KEPUTUSAN PENERIMAAN KARYAWAN BARU DENGAN ALGORITMA GREEDY," Jurnal Visualika, vol. 6, no. 2, pp. 154-160, 2020.

[5] N. K. Dewi, I. Mulyana, A. S. Putra and F. R. Radita, "Konsep Robot Penjaga Toko Di Kombinasikan Dengan Pengendalian Virtual Reality (VR) Jarak Jauh," IKRA-ITH INFORMATIKA: Jurnal Komputer dan Informatika, vol. 5, no. 1, pp. 33-38, 2020.

[6] B. Givan, R. Amalia, A. I. Sari, S. H. Winarno and A. S. Putra, "Effective Use of E-Money through Online Shopping in E-Commerce," International Journal of Educational Research \& Social Sciences, vol. 2, no. 6, pp. 1692-1697, 2021.

[7] D. Novitasari, A. Masduki , P. AGUS , I. Joni , S. Didi ,. S. Nelson and S. P. Arman , "Peran Social Support terhadap Work Conflict, Kepuasan dan Kinerja," JPIM (JURNAL PENELITIAN ILMU MANAJEMEN), pp. 187-202, 2020.

[8] R. Wirawan, N. Aisyah, A. Rahman, B. S. Rahmawati, A. Medikano, A. Sebayang and A. S. Putra, "Perancangan Aplikasi Website Menggunakan Macromedia Dreamweaver Mx Untuk Budi Daya Anggrek (Studi Kasus Toko Anggrek Berseri)," TEKINFO, vol. 22, no. 2, pp. 77-86, 2021.

[9] V. Valentino, H. S. Setiawan, . A. Saputra, Y. Haryanto and A. S. Putra, "Decision Support System for Thesis Session Pass Recommendation Using AHP (Analytic Hierarchy Process) Method," Journal International Journal of Educational Research \& Social Sciences, pp. 215-221, 2021.

[10] . V. H. Valentino, H. S. Setiawan, M. T. Habibie, R. Ningsih, D. Katarina and A. S. Putra, "Online And Offline Learning ComparisonIn The New Normal Era," International Journal of Educational Research \& Social Sciences (IJERSC), vol. 2, no. 2, p. 449-455, 2021.

[11] M. Ulfa, "“Pengaruh Kecanduan Game Online Terhadap Perilaku Remaja Di Mabes Game Center Jalan Hr.Subrantas Kecamatan Tampan Pekanbaru"," Jom. Fisip Vol. 4 No. 1, pp. 1-13, 2017.

[12] R. N. Suryanto, "“Dampak Positif Dan Negatif Permainan Game Online Dikalangan Pelajar”," Jom Fisip Volume 2 No. $2,2015$.

[13] M. A. Suplig, "“Pengaruh Kecanduan Game Online Siswa Sma Kelas X Terhadap Kecerdasan Sosial Sekolah Kristen Swasta Di Makassar"," Jurnal Jaffray, Vol. 15, No. 2,, pp. 77-200, 2017.

[14] H. Sugiarto, I. Sumadikarta, M. Ryansyah, M. H. Fakhriza and A. S. Putra, "Application Design" Test Job Application" On Android OS Using The AHP Algorithm," International Journal of Educational Research \& Social Sciences, vol. 2, no. 5, pp. 1173-1180, 2021.

[15] M. Subani, I. Ramadhan, S. and A. S. Putra, "Perkembangan Internet of Think (IOT) dan Instalasi Komputer Terhadap Perkembangan Kota Pintar di Ibukota Dki Jakarta," IKRA-ITH INFORMATIKA: Jurnal Komputer dan Informatika, vol. 5, no. 1, pp. 88-93, 2020.

[16] A. Saputra, A. Fahrudin, A. S. Putra, N. Aisyah and V. Valentino, "The Effectiveness of Learning Basic Mathematics through Dice Games for 5-6 Years Old at TKIT Al-Muslim," International Journal of Educational Research \& Social Sciences, vol. 2, no. 6, pp. 1698-1703, 2021.

[17] E. Rubawati, "Media Baru: Tantangan dan Peluang Dakwah," Jurnal Studi Komunikasi http://ejournal.unitomo.ac.id/index.php/jsk, pp. 126 - 142, 2018.

[18] P. Roza, "DIGITAL CITIZENSHIP: MENYIAPKAN GENERASI MILENIAL MENJADI WARGA NEGARA DEMOKRATIS DI ABAD DIGITAL," Journal Sosioteknologi Volume 19, No 2, Agustus 2020, pp. 190-202, 2020.

[19] P. M. Risnadinata, I. Kumara and W. Ariastina, "Management of Flood Protection System of Dewa Ruci Underpass in Bali," Journal of Electrical, Electronics and Informatics, Vol. 4 No. 2, August 2020, pp. 57-63, 2020.

[20] D. D. A. P. Riani Muharomah, "“Analisis Run-Off Sebagai Dampak Perubahan Lahan Sekitar Pembangunan Underpass Simpang Patal Palembang Dengan Memanfaatkan Teknik Gis”," 2014.

[21] M. H. Riandi, H. Respati and S. Hidayatullah, "Conceptual Model of User Satisfaction as Mediator of E-Learning Services and System Quality on Students' Individual Performance," International Journal of Research in 
Engineering, Science and Management, vol. 4, no. 1, pp. 60-65, 2021.

[22] I. Ramadhan, A. Kurniawan and A. S. Putra, "Penentuan Pola Penindakan Pelanggaran Lalu Lintas di DKI Jakarta Menggunakan Metode Analytic Network Process (ANP)," IKRA-ITH INFORMATIKA: Jurnal Komputer dan Informatika, vol. 5, no. 1, pp. 51-57, 2020.

[23] A. S. Putra, "Konsep Kota Pintar Dalam Penerapan Sistem Pembayaran Menggunakan Kode QR Pada Pemesanan Tiket Elektronik," TEKINFO Jurnal Ilmiah Teknik Informatika, vol. 21, pp. 1-15, 2020.

[24] A. S. Putra, "Teknologi Informasi (IT) Sebagai Alat Syiar Budaya Islam Di Bumi Nusantara Indonesia," Seminar Nasional Universitas Indraprasta (SINASIS), pp. 200-215, 2020.

[25] A. S. Putra, "Peran Sosial Media Sebagai Media Dakwah Di Zaman Pandemic Virus Corona Atau Covid 19 Di Indonesia," Panangkaran: Jurnal Penelitian Agama dan Masyarakat, pp. 1-12, 2021.

[26] A. S. Putra, "PENTING NYA KESADARAN HUKUM RAKYAT INDONESIA DI BIDANG TEKNOLOGI INFORMASI DI TINJAU DARI KEBERADAAN CYBERCRIME," Seminar Nasional Inovasi dan Teknologi (SNIT) BSI, pp. 36-50, 2012.

[27] A. S. Putra and . H. Kusuma, "Pengembangan Sistem Career Center untuk Departemen Konseling dan Pengembangan Karir di Institut Teknologi Budi Utomo," Jurnal Khatulistiwa Informatika, pp. 133-143, 2015.

[28] A. S. Putra, "Penerapan Konsep Kota Pintar dengan Cara Penerapan ERP (Electronic Road Price) di Jalan Ibu Kota DKI Jakarta. Jurnal Informatika Universitas Pamulang, 5(1), 13-18.," Jurnal Informatika Universitas Pamulang, 5(1), 13-18., pp. 13-18, 2020.

[29] A. S. Putra and . R. R. Fatrilia, "Paradigma Belajar Mengaji Secara Online Pada Masa Pandemic Coronavirus Disease 2019 (Covid-19)," MATAAZIR: Jurnal Administrasi dan Manajemen Pendidikan, pp. 49-61, 2020.

[30] A. S. Putra and L. H. S. W. Harco, "Intelligent Traffic Monitoring System (ITMS) for Smart City Based on IoT Monitoring," Indonesian Association for Pattern Recognition International Conference (INAPR) IEEE, pp. 161$165,2018$.

[31] A. S. Putra, L. H. S. W. Harco , S. A. Bahtiar, T. Agung, . S. Wayan and H. K. Chu-, "Gamification in the eLearning Process for children with Attention Deficit Hyperactivity Disorder (ADHD)," Indonesian Association for Pattern Recognition International Conference (INAPR) IEEE, pp. 182-185, 2018.

[32] A. S. Putra, L. H. S. W. Harco , L. G. Ford , . S. Benfano and A. Edi , "A Proposed surveillance model in an Intelligent Transportation System (ITS)," Indonesian Association for Pattern Recognition International Conference (INAPR) IEEE, pp. 156-160, 2018.

[33] A. S. Putra, "'Penggabungan Wilayah Kota Bekasi Dan Kota Tangerang Ke Wilayang Ibu Kota DKI Jakarta Berdasarkan Undang-Undang Nomor 23 Pasal 32 Tahun 2019 Dapat Membantu Mengwujudkan DKI Jakarta Menjadi Kota Pintar"," Jurnal IPSIKOM VOL 7 No. 2, 2019.

[34] A. S. Putra, H. L. H. S. Warnars, B. S. Abbas, A. Trisetyarso, W. Suparta and C.-. Ho Kang, "“Gamification in the e-Learning Process for children with Attention Deficit Hyperactivity Disorder (ADHD)"," 1 st 2018 Indonesian Association for Pattern Recognit INAPR, pp. 182-185, 2019.

[35] A. S. Putra, " "Smart City : konsep Kota pintar di DKI Jakarta"," Jurnal TEKINFO, Vol 20, No 2, Hal 1-111, ISSN 1411-3635, 2019.

[36] A. S. Putra, " "Smart City : Ganjil Genap Solusi Atau Masalah Di DKI Jakarta”," Jurnal IKRA-ITH Informatika Vol 3 No 3, ISSN 25804316, , 2019.

[37] E. K. Laksanawati and S. P. Arman, "ANALISA STUDI CONFORMITY OF PRODUCTION (COP) UNTUK DITERAPKAN DI BALAI PENGUJIAN LAIK JALAN DAN SERTIFIKASI KENDARAAN BERMOTOR (BPLJSKB) BEKASI," Prosiding Seminar Nasional Aplikasi Sains \& Teknologi (SNAST), pp. 207-214, 2014.

[38] D. E. Kurniawan, "“Pengaruh Intensitas Bermain Game Online Terhadap Perilaku Prokrastinasi Akademik Pada Mahasiswa Bimbingan Dan Konseling Universitas Pgri Yogyakarta"," Jurnal Konseling Gusjigang Vol. 3 No. 1 (Januari-Juni 2017) Print Issn 246, 2017.

[39] D. Katarina, A. Nurrohman, w. and A. S. Putra, "Decision Support System For The Best Student Selection Recommendation Using Ahp (Analytic Hierarchy Process) Method," International Journal of Educational Research \& Social Sciences, vol. 2, no. 5, pp. 1210-1217, 2021.

[40] K. Jacksi, M. A. Sulaiman and R. H. Saeed, "The Importance of E-Learning in the Teaching Processor Secondary Schools /Review Article," Academic Journal of Nawroz University (AJNU), Vol.10, No.1, Jan 2021, vol. 10, pp. 
53-62, 2021.

[41] R. Hermawan, M. T. Habibie, D. Sutrisno, A. S. Putra and N. Aisyah, "Decision Support System For The Best Employee Selection Recommendation Using Ahp (Analytic Hierarchy Process) Method," International Journal of Educational Research \& Social Sciences, vol. 2, no. 5, pp. 1218-1226, 2021.

[42] M. S. Hartawan, A. S. Putra and A. Muktiono, "Smart City Concept for Integrated Citizen Information Smart Card or ICISC in DKI Jakarta," International Journal of Science, Technology \& Management, pp. 364-370, 2020.

[43] B. Givan, . R. Wirawan, D. Andriawan, N. Aisyah, A. and A. S. Putra, "Effect of Ease And Trustworthiness To Use E-Commerce for Purchasing Goods Online," International Journal of Educational Research \& Social Sciences (IJERSC), vol. 2, no. 2, p. 277-282, 2021.

[44] H. W. Fauzi, S. and S. Anwar, "ANALISIS PENGEMBANGAN JALAN TIDAK SEBIDANG (UNDERPASS) DI JALAN JENDERAL SUDIRMAN - JALAN SULTAN AGUNG KABUPATEN BREBES," Jurnal Konstruksi, Vol. VI , No. 3, Januari 2017, pp. 255-268, 2017.

[45] P. K. Dhamarsa, Safrizal, . S. P. Arman and Suyanto, "Perancangan Aplikasi ITBU Career Center Berbasis Website Menggunakan PHP dan MYSQL," TEKINFO UPI YAI, pp. 1-105, 2019.

[46] N. K. Dewi and A. S. Putra, "Prosiding International Conference of Universitas Pekalongan," Prosiding International Conference on Education of Suryakancana 2021 (ICONNECTS 2021), pp. 321-326, 2021.

[47] N. K. Dewi and A. S. Putra, "LAW ENFORCEMENT IN SMART TRANSPORTATION SYSTEMS ON HIGHWAY," Proceedings International Conference onEducation of Suryakancana 2021, pp. 321-326, 2021.

[48] N. K. Dewi, . B. H. Irawan, E. Fitry and A. S. Putra, "Konsep Aplikasi E-Dakwah Untuk Generasi Milenial Jakarta," IKRA-ITH INFORMATIKA: Jurnal Komputer dan Informatika, vol. 5, no. 2, pp. 26-33, 2020.

[49] N. K. Dewi and A. S. Putra, "Decision Support System for Head of Warehouse Selection Recommendation Using Analytic Hierarchy Process (AHP) Method," Prosiding International Conference of Universitas Pekalongan, pp. $1-12,2021$.

[50] A. Damuri, N. Isnain, R. A. Priyatama, Y. I. Chandra and A. S. Putra, "E-Learning Proposal System in Public Secondary School Learning," International Journal of Educational Research \& Social Sciences (IJERSC), vol. 2, p. 270-275, 2021.

[51] H. W. F. G. B. S. E. A. Arman Syah Putra, " “A Proposed surveillance model in an Intelligent Transportation System (ITS)"," 1st 2018 Indonesian Association for Pattern Recognition International Conference, INAPR, 2019.

[52] A. S. Putra, "Efektifitas Sistem Jalan Underpass untuk Kota Pintar DKI Jakarta," Jurnal Informatika Universitas Pamulang, vol. 5, no. 3, pp. 220-227, 2020.

[53] A. S. Putra, "Analisa Dan Perancangan Sistem Pembelian Makanan Di Restoran Pada Masa Pandemic Coronavirus Disease 2019 (Covid-19)," Jurnal Esensi Komputasi (Jurnal Esensi Sistem Komputer dan Informasi ), vol. 4, no. 2, pp. 10-15, 2020.

[54] A. S. Putra, H. Warnars, F. Gaol, B. Soewito and E. Abdurachman, "A Proposed surveillance model in an Intelligent Transportation System (ITS)," 1 st 2018 Indonesian Association for Pattern Recognition International Conference, INAPR 2018 - Proce vol. , 25, pp. 1-10, January 2019. 